\title{
Modeling Extreme Conditions of Sewage Plumes in Central - South Coastal Region of São Paulo State - Brazil
}

Samuel Hora Yang / Joseph Harari

DOI 10.4322/dae.2016.017

\section{ABSTRACT}

The study region is located in the central-south coast of Sao Paulo State (Brazil), centered at $24.5^{\circ} \mathrm{S}-46.5^{\circ} \mathrm{W}$, and is influenced by three outfalls of the city of Praia Grande and sewage releases by Itanhaem River. The objective of this study is analyzed the dispersion of effluent plumes emitted by the submarine outfalls and the Itanhaem River, concerning the concentration of contaminants in extreme conditions (summer month). For that, Delft3D model's hydrodynamic and water quality modules were used, as well as the Visual Plumes model. Results of hydrodynamic simulations were consistent with the hydrodynamics features established in the literature. The near-field modeling showed the influence of currents in the transport and initial dilution of effluent plumes. The far-field modeling's results of the plumes from the submarine outfalls and Itanhaem River showed that those plumes do not exceed the maximum levels established by the National Environmental Council when reaching the shore. Once observations indicate that the local beaches are often classified as inappropriate for bathing and with bad water quality, streams that dump raw and untreated sewage directly on the beaches can be identified as the responsible for the environmental contamination of the study area shore.

Keywords: Marine pollution, submarine outfall, sewage, numerical modeling, water quality, VP, UM3, Delft3D.

\section{RESUMO}

A região de estudo está localizada no litoral centro-sul do Estado de São Paulo (Brasil), centrado em 24,5 ${ }^{\circ} \mathrm{S}-46,5^{\circ} \mathrm{W}$, e é influenciada por três emissários da cidade de Praia Grande e lançamentos de esgoto pelo rio Itanhaém. $\mathrm{O}$ objetivo deste estudo foi analisar a dispersão das plumas dos efluentes emitidos pelos emissários submarinos e do Rio Itanhaém, sobre a concentração de contaminantes em condições extremas (mês de verão). Para isso, foram utilizados módulos de qualidade de água e hidrodinâmicas do modelo Delft3D, bem como o modelo Visual Plumes. Os resultados das simulações hidrodinâmicas foram consistentes com as características hidrodinâmicas estabelecidas na literatura. A modelagem de campo próximo mostrou a influência das correntes no transporte e diluição inicial de plumas de efluentes. Os resultados das simula-

Samuel Hora Yang.

Instituto de Energia e Ambiente da Universidade de São Paulo, samuel_tristarahotmail.com Joseph Harari

Instituto Oceanográfico da Universidade de São Paulo, joharariausp.br 
ções de campo-distante da modelagem das plumas dos emissários submarinos e Rio Itanhaém mostraram que as plumas não excedam os níveis máximos estabelecidos pelo Conselho Nacional do Meio Ambiente ao atingir a costa. Uma vez que as observações indicam que as praias locais são geralmente classificadas como impróprias para o banho e com má qualidade da água, o esgoto bruto despejado através dos córregos ou diretamente nas praias pode ser identificado como o responsável pela contaminação ambiental da costa na área de estudo.

Palavras-chave: poluição marinha, emissário submarino, esgoto, modelagem numérica, qualidade da água, VP, UM3, Delft3D.

\section{INTRODUCTION}

In outfalls, usually the sewage passes through only preliminary treatment, with subsequent disinfection with chlorine. However, when dumping untreated sewage, the sea allows dilution. After the sewage is dumped into the marine environment, either by a submarine outfall or through streams that flow into the sea, the mixture of effluents then occurs. In the case of emissaries, the mixture takes place in three zones, with different spatial-temporal scales: near field, intermediate field and far field (Lamparelli, 2007; Harari et al., 2013; Gregorio, 2009; Delfim, 2011; Subtil, 2012).

The region of near-field has interactions with the surface, the pycnocline region and the bottom, with great influence of physical processes and pipe diffusing features, which can significantly affect the initial mixture. In the near field, the spatial scale is of the order of 10 to $100 \mathrm{~m}$, while the timescale is in the range of seconds to minutes.

The region of intermediate-field is the zone of stability between the regions of near and far fields, and has a dynamic dependence on the momentum and buoyancy forces of sewage discharge and the local current intensities. Its spatial and time scales are typically from 100 to $1000 \mathrm{~m}$ and from minutes to hours, respectively. From that point, with the hydrostatic equilibrium achieved, is characterized the presence of the far-field region, where the effluent begins to behave like a plume, whose dispersion is controlled by advection and diffusion processes. In the far-field, the spatial scale is approximately $10^{3}-10^{5}$ meters while the time scale ranges in order of hours to days.

The near-field models are used to simulate the mixing processes in the initial release region, being dependent on both environmental factors (such as intensity of currents, stratification of the water column and the sea turbulence), as well as releasing features (number of emitting orifices, their dimensions, etc.). Moreover, far-field models are used to simulate the dispersion of sewage without the need to take into account how is performed their release into the marine environment, being used for simulations of effluent dispersion in coastal regions and estuaries, starting from previously obtained results of near field models (Delfim, 2011).

In the study region, centered on $24.5^{\circ} \mathrm{S} 46.5^{\circ} \mathrm{W}$, are installed three outfalls, all in the municipality of Praia Grande, called Praia Grande I (PG 1, $24.01^{\circ} \mathrm{S} 46.40^{\circ} \mathrm{W}$ ), Praia Grande II (PG 2, $24.05^{\circ} \mathrm{S}$ $46.44^{\circ} \mathrm{W}$ ) and Praia Grande III (PG 3, $24.09^{\circ} \mathrm{S}$ $\left.46.53^{\circ} \mathrm{W}\right)$ (SABESP, 2010). 
However, the cities of Peruibe, Itanhaem and Mongaguado not have outfalls, and discharge part of their wastewater without any proper treatment, directly into streams, estuaries and the sea (Jakob, 2002). One of the main destinations of these effluents is the Itanhaem River $\left(24.20^{\circ} \mathrm{S} 46.80^{\circ} \mathrm{W}\right)$, whose estuary has typical vegetation of mangroves and is greatly influenced by the sea (Souza Pereira \& Camargo, 2004).

\section{OBJECTIVES}

The main objective of this study was to analyze the dispersion of the effluent plumes emitted by outfalls of Praia Grande and the Rio Itanhaem, through numerical modeling.

\section{METHODOLOGY}

Delft3D is a model used to perform numerical simulations, determining spatial and temporal variations and interactions between hydrodynamic phenomena, sediment, ecology and water quality, especially in natural environments such as coastal regions, rivers and estuaries, but also in artificial coastal environments, as ports and docks (Deltares, 2013).

It was established in Delft3D (D3D) a grid model to cover the region of interest for the hydrodynamic modeling, in spherical coordinates, type $\mathrm{C}$ of Arakawa (Mesinger \& Arakawa, 1976). This computational grid contains 227 by 227 horizontal cells, being inclined at $45^{\circ}$ counterclockwise with horizontal spacing of $350 \mathrm{~m}$, and vertical spacing comprising five equidistant sigma layers (Harari et al., 2006).

The water quality module Delft3D D3D-WAQ allows physical and chemical processes specific to each pollutant to be activated independently, aiming the creation of scenarios to represent real dispersion and decay of pollutants into the environment (Deltares, 2013a).
Visual Plumes software (VP), Version 1.0, was used (Frick et al., 2001; Frick, 2004), for modeling the near and intermediate field due to sewage discharge from the three emissaries, more specifically, its module Three Dimensional Updated Merge (UM3). Mixing processes in the initial region were simulated from: technical information of the outfalls; concentration values and decay of the concerned pollutants; and results of D3D-FLOW in hydrodynamics characterization of environment where sewage plumes were released.

The UM3 is a Lagrangian 3D model of initial dilution of the plume, through the equations of conservation of mass, horizontal momentum and energy; UM3 performs near-field and intermediate- field simulations of plumes derived from ocean outfalls (Baumgartner, Frick \& Roberts, 1994).

The fecal coliform pollutant Escherichia coli (E.coli) were selected for this study. The upper limit for a coastal water to be considered as appropriate for bathing, as function of E.coli concentration, is $800 \mathrm{MPN} / 100 \mathrm{ml}$, in at least $80 \%$ of the samples (BRASIL, 2001).

Information of concentrations of the pollutants discharged by outfalls were obtained from SABESP (2010), IBGE (2015), Marcellino (2004) and Macedo et al. (2009); details can be found in Yang (2016).

Values of concentrations of pollutants released by Rio Itanhaem were obtained in Quiñones (2000), for the periods of summer (January and February) of 1998. The release of pollutants was continuous and constant along time. Temperature and salinity values were obtained at the river mouth following Souza Pereira \& Campbell (2004). On the other hand, values of the average monthly discharges of Rio Itanhaem were obtained in DAEE (2015).

The hydrodynamics and the near, intermediate and distant field modeling was performed to 
February 2012, considered an extreme case because it is a summer month, with a large number of tourists. As the research aimed to monitor the pollution plumes only due to the outfalls of Praia Grande and Rio Itanhaem discharge, it was used, as an initial condition, zero concentration values across the entire grid.

\section{RESULTS}

In this section will initially be presented a selection of modeling results of plumes, referring to the near and intermediate fields (VP model results), for February 2012, with angular histograms of dilution, travelled distance and concentration of $\mathrm{E}$. coli (Figure 1).

Next, time series of E.coli concentrations, at the surface and the bottom, are presented in Figures 2 and 3 , as given by the far-field modeling results for February 2012. Finally, Figures 4 and 5 show distributions of $E$. coli at the surface and bottom, in the periods of maximum values in Praia Grande and Rio Itanhaem, in February 2012.
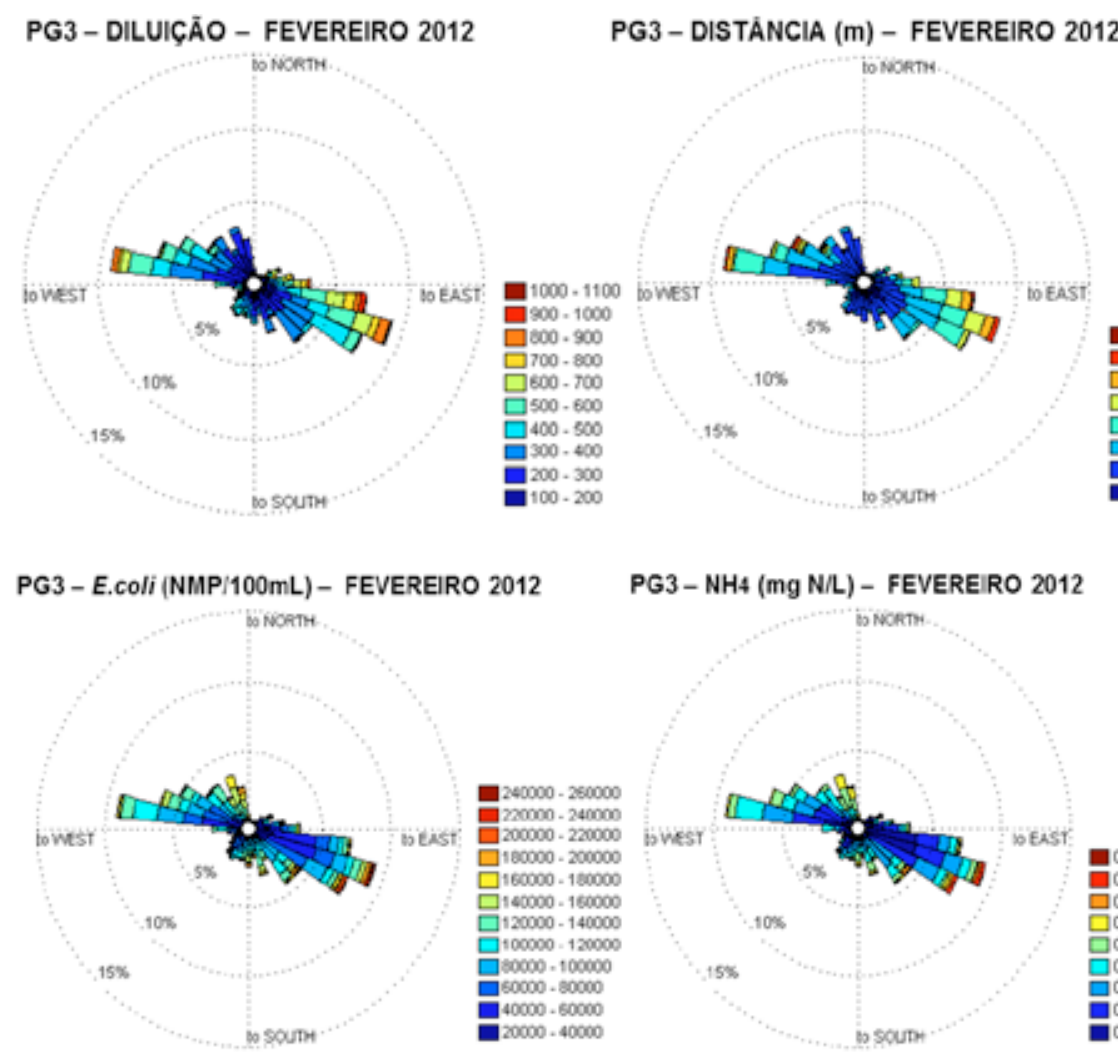
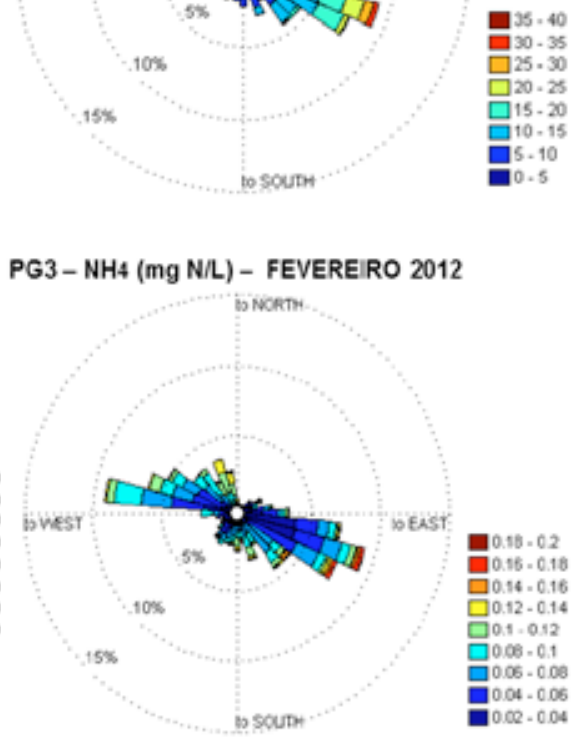

Figure 1: Angular histograms of dilution, travelled distance and concentration of E. coli plumes of PG3 emissary to each of its diffusers, in February 2012. 

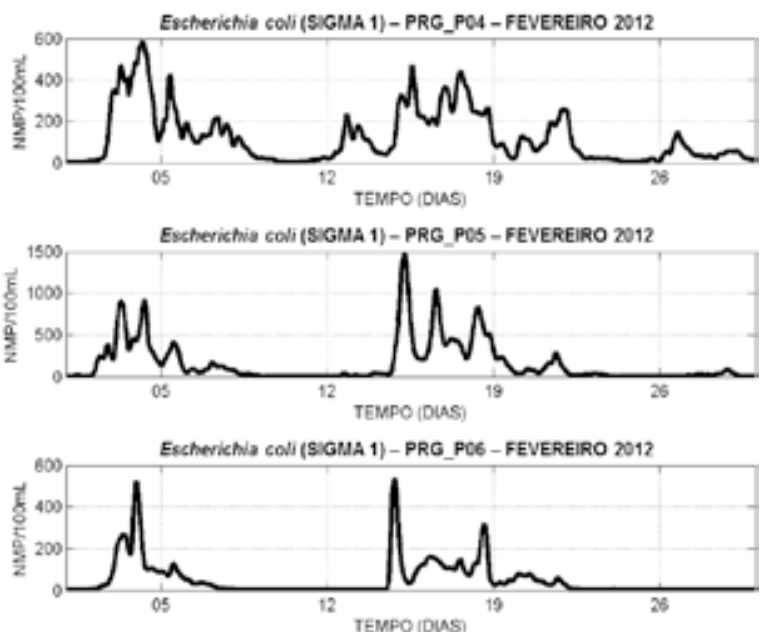
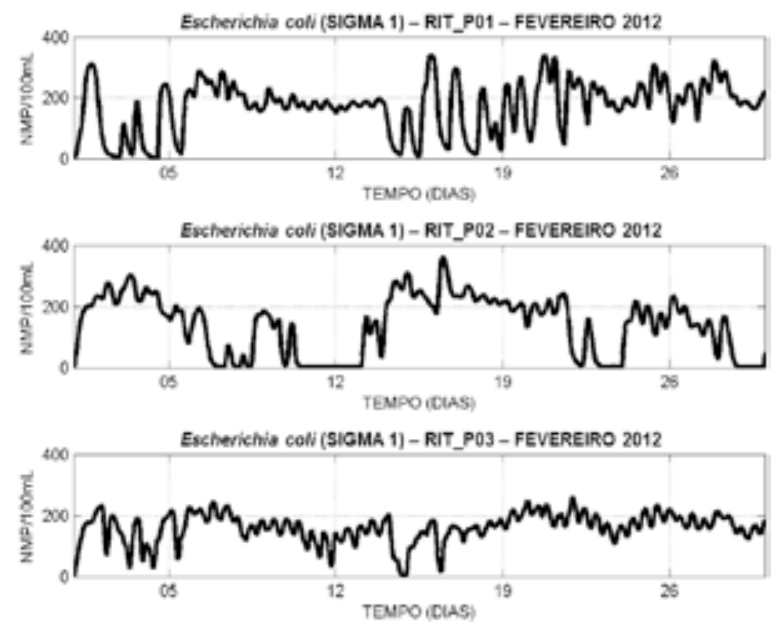

Figure 2: Time series of E. coli at the surface, in points PRG_P05 (24.40 $\left.46.45^{\circ} \mathrm{W}\right)$ and RIT_03 (24.20 $\left.{ }^{\circ} \mathrm{S} 46.78 \mathrm{~W}\right)$, for the month of February 2012
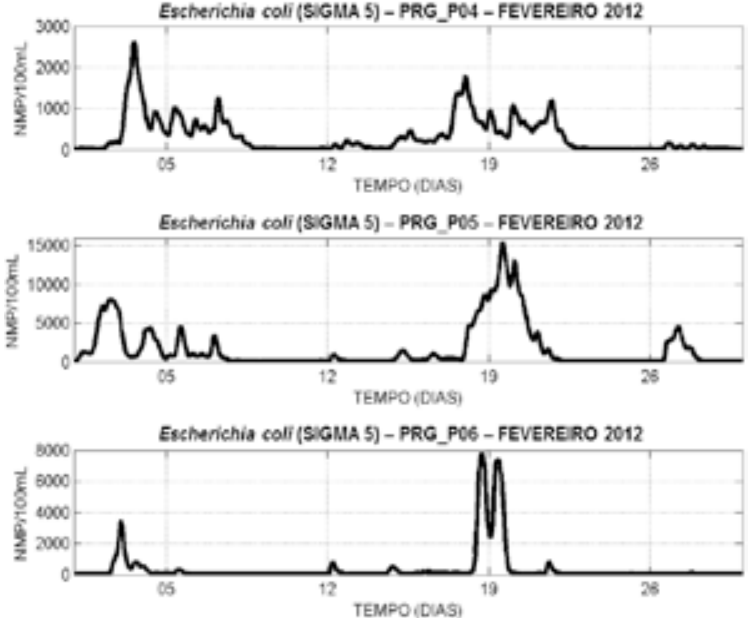

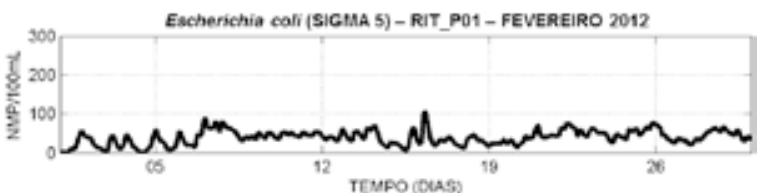

Escherichía cali (SIGMA 5) - RIT_P02 - FEVEREIRO 2012

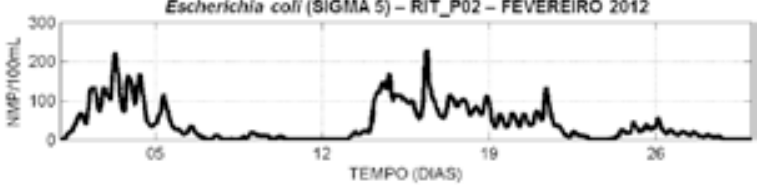

Escherichia cali (SIGMA 5) - RIT_P03 - FEVEREIRO 2012

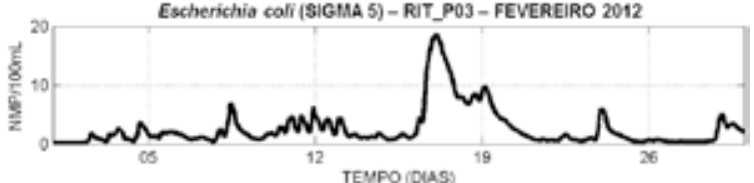

Figure 3: Time series of E. coli on the bottom, in points PRG_P05 $\left(24.40^{\circ} \mathrm{S} 46.45^{\circ} \mathrm{W}\right)$ and RIT_03 $\left(24.20^{\circ} \mathrm{S} 46.78 \mathrm{~W}\right)$, for the month of February 2012
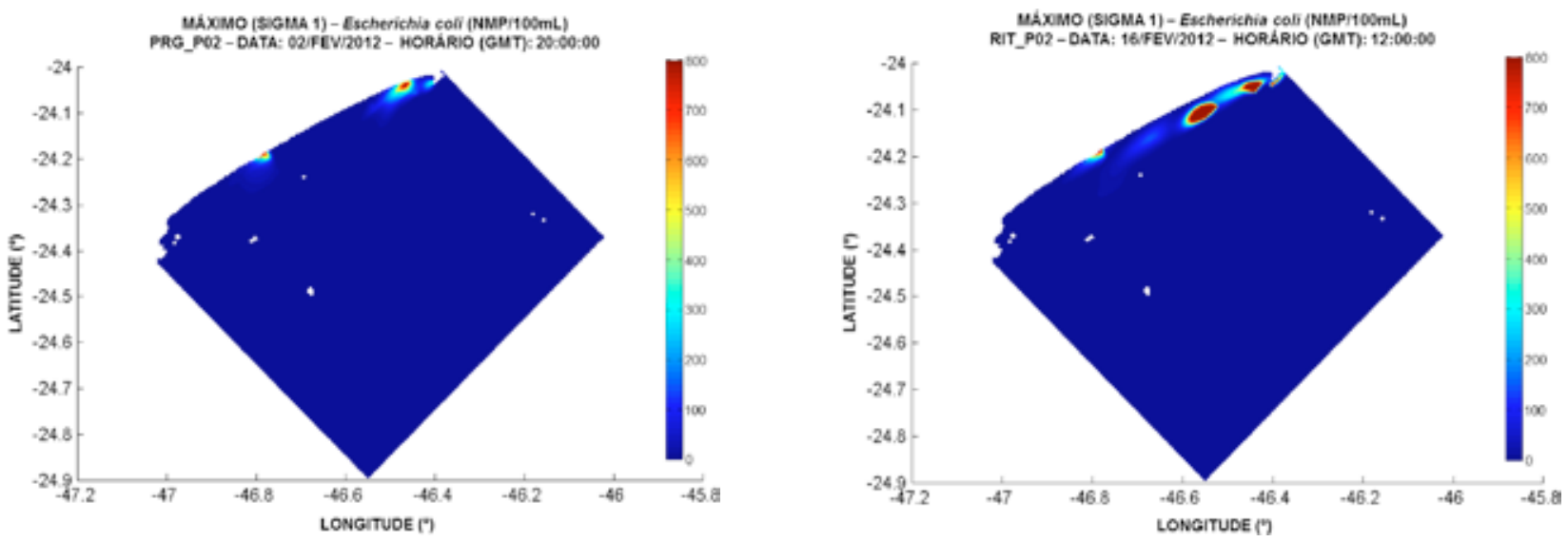

Figure 4: Distributions of E. coli at the surface, at the period of maximum values in Praia Grande (above) and Rio Itanhaem (below), in February 2012. 

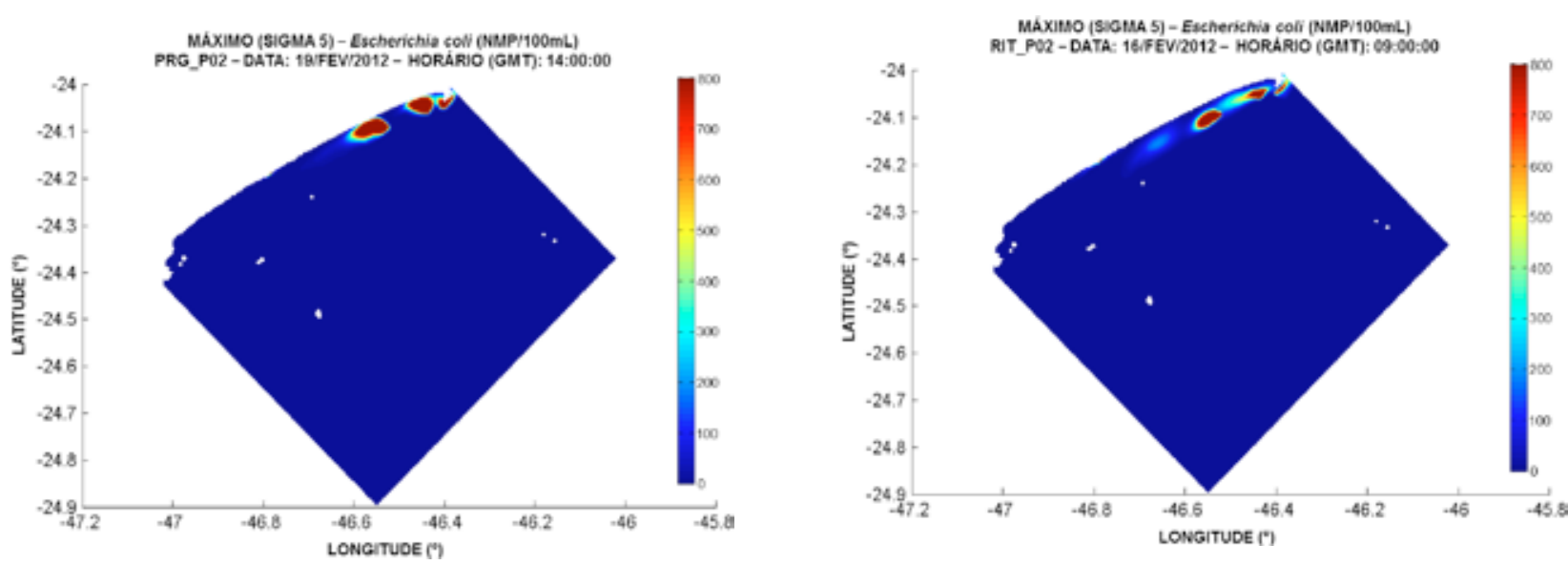

Figure 5 - Distributions of E. coli on the bottom, at the period of maximum values in Praia Grande (above) and Rio Itanhaem (below), in February 2012.

\section{DISCUSSION}

The maps of pollutant plumes distribution show that the entire coastal strip, until approximately the depths of 25 to $30 \mathrm{~m}$, is subject to the impacts of effluent plumes coming from Praia Grande emissaries and the mouth of the Rio Itanhaem, both in surface layer and the bottom layer.

As for time series and statistical calculations, concentrations were reported for Escherichia coli above 800 MPN / 100ml limit in most cases, much of simulated time, in points located between the outfalls as well as at points located in their vicinity.

In points located on the beaches of the municipalities of Praia Grande and Itanhaem, no model result exceeded the E.coli limit of saline water Class 1 considered as appropriate for bathing. This is because the concentration of a pollutant decrease due to the dispersion of the plumes, so the tendency is to occur a gradual reduction of the concentration of coliforms according to the distance covered by the plumes; in fact, there is a high dynamism of the sewage purification process (Ferreira, 2015), which in the case of fecal coliforms is a function of incident solar radiation, chlorinity and temperature of seawater. As for the area near the mouth of the Rio Itanhaem, besides the resulting plumes of Praia Grande emissaries are already with significantly reduced coliform concentrations to reach this area, the river plume has less potential pollution plumes than of the three submarine emissaries, due to the initial values of E.coli considered.

Monitoring of beaches of the municipality of Itanhaem, carried out by CETESB (2013), showed the same percentage of time with adequate water quality as given by D3D-WAQ results. However, the model results and in situ sampling on the beaches of Praia Grande did not agree, and one possible explanation for this discrepancy is that the simulations in D3D-WAQ model considered as polluting sources only the three outfalls of Praia Grande and the Rio Itanhaem discharges, while the in situ samples had the influence of other sources of pollution in the coastal region, such as streams that dump raw sewage directly into the Praia Grande coast (SABESP, 2010). When pollution of these streams joins with the plumes of the emissaries, results an increased concentration of coliforms, which can exceed the bathing limits, making the beaches improper for use by bathers. 


\section{CONCLUSIONS}

According to the annual reports of beaches quality of Sao Paulo State, published by CETESB (2013), the Praia Grande, Mongagua, Itanhaem and Peruibe beaches have registered improper conditions of bathing, especially during the summer months. The use of D3D-WAQ model, together with the hydrodynamic results of D3D-FLOW, for monitoring the dispersion of plumes of emissaries PG1, PG2 and PG3 and Rio Itanhaem, showed that their plumes hit the coast until the depths of about 25 to $30 \mathrm{~m}$. However, pollution from such sources at local beaches does not exceed the limits of bathing, being above the limit values only near the outfalls. Therefore, one can say that the Praia Grande outfalls are well sized and operate correctly, and, along with the Rio Itanhaem, cannot be considered as responsible for improper bathing beaches in the region.

In the case of Praia Grande, where bathing in general remained improper in most of the beaches in the summer of 2012 (CETESB, 2013), the 10 streams that flow directly in the coastal area of the city can be considered as the major responsible for pollution and poor water quality in its coastline, as they bring raw and untreated sewage directly to the beaches (SABESP, 2010).

\section{REFERENCES}

BAUMGARTNER, D.J.; FRICK, W.E. \& ROBERTS, P.J.W. Dilution models for effluent discharges. 3rd edition. Portland (OR, USA): United States Environmental Protection Agency (USEPA), 1994. 189p. BRASIL. Resolução N. ${ }^{\circ} 274$ de 29 de novembro de 2000. Diário Oficial da União, Brasília (DF), N.¹8: pp. 70-71, janeiro 2001.

CETESB. Qualidade das praias litorâneas no estado de São Paulo - 2015. Relatório técnico. São Paulo (SP): CETESB, 2013. 188p.

DAEE. Hidrologia: banco de dados hidrológicos. São Paulo (SP): 2015. Disponível em: <http://www.hidrologia.daee.sp.gov.br/>. Acesso em: 14 maio 2015.

DELFIM, V. Modelagem e análise do lançamento de efluentes através de emissário submarino - Região do Campeche, Florianópolis, SC. Monografia de Bacharelado, Centro de Ciências Tecnológicas da Terra e do Mar da Universidade do Vale do Itajaí (CTTMar - Univali), Graduação em Oceanografia, Itajaí (SC): 2011. 66p.
DELTARES. Delft3D-FLOW User Manual: simulation of multi-dimensional hydrodynamics flows and transport phenomena, including sediments. Version 3.15.26466. Delft (Netherlands): Deltares Systems, 2013. 676p.

DELTARES. D-Water Quality User Manual: versatile water quality modeling in 1D, 2D or 3D systems including physical, (bio) chemical and biological processes. Version 4.99.29153. Delft (Netherlands): Deltares Systems, 2013a. 394p.

FERREIRA, F.R. Análise da qualidade ambiental das praias do Guarujá (SP) através da avaliação de lançamentos pontuais de esgotos - emissário submarino do Guarujá, canais artificiais e rios da Praia do Perequê. Dissertação de Mestrado, Instituto de Energia e Ambiente da Universidade de São Paulo (IEE USP), Programa de Pós-Graduação em Ciência Ambiental, São Paulo (SP): 2015. 134p.

FRICK, W.E. Visual Plumes mixing zone modeling software. Environmental Modeling \& Software, 19(5): pp. 645-654, 2004.

FRICK, W.E.; ROBERTS, P.J.W.; DAVIS, L.R.; KEYES, J.; BAUMGARTNER, D.J. \& GEORGE, K.P. Dilution models for effluent discharges: Visual Plumes. 4th edition. Athens (GA, USA): United States Environmental Protection Agency (USEPA), 2001. 136p.

GREGORIO, H.P. Modelagem numérica da dispersão da pluma do emissário submarino de Santos. Dissertação de Mestrado, Instituto Oceanográfico da Universidade de São Paulo (IOUSP), Programa de Pós-Graduação em Oceanografia Física, São Paulo (SP): 2009. 108p.

HARARI, J.; FERREIRA, F.R.; DEGASPARI, F.A. \& SARTOR, S.M. Modelagem numérica da hidrodinâmica e da dispersão de esgoto na Baía de Santos, SP. Revista Brasileira de Recursos Hídricos, Porto Alegre (RS), 18(1): pp. 205-214, janeiro/março 2013.

IBGE. Estimativas da população residente nos municípios brasileiros com data de referência em $1^{\circ}$ de julho de 2015. Relatório técnico. Rio de Janeiro (RJ): Diretoria de pesquisas / Coordenação de população e indicadores sociais do Instituto Brasileiro de Geografia e Estatística (DPE/COPIS IBGE), 2016. 127p.

JAKOB, A.A.E. A Krikagem como método de análise de dados demográficos. In: Anais do $13^{\circ}$ Encontro da Associação Brasileira de Estudos Populacionais, Ouro Preto (MG), 2002. pp. 1-21.

LAMPARELLI, C.C. Desafios para o licenciamento e monitoramento ambiental de emissários: a experiência de São Paulo. In: LAMPARELLI, C.C. \& ORTIZ, J.P. Emissários submarinos: projeto, avaliação de impacto ambiental e monitoramento. São Paulo (SP): CETESB, 2007, pp. 11-23.

MACEDO, L.S.; NARDUCCI, L.; CIRELLI, J. \& ALÁRIO, L.A.N. A utilização de metodologia não destrutiva na implantação do trecho de arrebentação do emissário do subsistema III da Praia Grande. Revista DAE, São Paulo (SP), N. ${ }^{0180:}$ pp. 32-43, maio 2009. 
MARCELLINO, E.B. Análise e recomendações para a capacidade atual de interceptação e disposição oceânica de esgotos dos subsistemas I e II: município de Praia Grande. Relatório técnico. São Paulo (SP): SABESP, 2004. 67p.

MESINGER, F. \& ARAKAWA, A. Numerical methods in atmospheric models. Technical report. Volume 1, Global Atmospheric Research Program Publication Series 17. Geneva (Switzerland): World Meteorological Organization, 1976. 64p.

QUIÑONES, E.M. Relações água-solo no sistema ambiental do estuário de Itanhaém (SP). Tese de Doutorado, Faculdade de Engenharia Agrícola da Universidade Estadual de Campinas (FEAGRI - UNICAMP), Programa de Pós-Graduação em Engenharia Agrícola, Campinas (SP): 2000. 185p.

SABESP. Termo de Referência para Prestação dos Serviços de Monitoramento: Plano de Monitoramento - Maio/2010. Relatório técnico. São Paulo (SP): SABESP, 2010. pp. 104-109.
SOUZA-PEREIRA, P.E. \& CAMARGO, A.F.M. Efeito da salinidade e do esgoto orgânico sobre a comunidade zooplanctônica, com ênfase nos copépodes, do estuário do Rio Itanhaém, Estado de São Paulo. Acta Scientarium Biological Sciences, Maringá (PR), 26(1): pp. 9-17, 2004.

SUBTIL, E.L. Tratamento de águas residuárias utilizando emissários submarinos: avaliação do nível de tratamento para uma disposição oceânica absolutamente segura. Tese de Doutorado, Escola Politécnica da Universidade de São Paulo (POLI USP), Programa de Pós-Graduação em Engenharia Hidráulica e Sanitária, São Paulo (SP): 2012. 218p.

YANG, S. H. Análise de condições ambientais e plumas de efluentes na região costeira centro-sul do Estado de São Paulo através de modelagem numérica. 2016. Dissertação (Mestrado em Ciência Ambiental) - Programa de Pós-Graduação em Ciência Ambiental (PROCAM) - Instituto de Energia e Ambiente da Universidade de São Paulo (IEE USP), São Paulo (SP), 2016 